\title{
TRANSFORMATION OF LOYALTY TO E-LOYALTY
}

\author{
Elina RADIONOVA-GIRSA ${ }^{1}$, Anda BATRAGA ${ }^{2}$ \\ ${ }^{1,2}$ University of Latvia, Riga, Latvia \\ Corresponding author e-mail: elinaradionova@gmail.com
}

\begin{abstract}
As everyday life moves to the Internet, many factors and components have come up, with the "e" and e-loyalty not an exception. The authors focused on the transformation of loyalty to e-loyalty. It is important to understand the main differences between consumer loyalty models and e-loyalty models in order to promote business development not only in the traditional environment but also in the online environment. Such research methods as comparative analysis, analysis of the scientific literature, content analysis were used. The main focus of the research was on comparing loyalty models in the traditional and eenvironment to find out the peculiarities and main features of the e-environment. New factors that influence loyalty in the Internet environment, but not in the real world, were highlighted as the main results. All the new influencing factors are related to the company's operation directly in the Internet environment and technical capabilities, as well as online communication. As a result, factor groups influencing the primary and secondary e-loyalty were found. This is an important topic of the 21 st century, enabling businesses to move online mode and change their strategy according to the e-environment.
\end{abstract}

Keywords: e-loyalty, e-satisfaction, loyalty models, online environment, satisfaction.

\section{JEL Classification: M31}

\section{INTRODUCTION}

According to European Statistics Database "the proportion of individuals aged 16 to 74 in the EU-28 who ordered or bought goods or services over the internet for private use continued to rise: in 2018, it stood at $60 \%$, an increase of 13 percentage points when compared with 2013" and also customers started to order and use more facilities of the Internet and e-commerce. Customers or e-shoppers in the EU according to Eurostat data purchased such goods and services as clothes and sport goods (64 \% of e-buyers), travel and holiday accommodation (53\%). Those who are aged 16-24 prefer to buy clothes and sports goods online (72\%), customers aged $25-54$ buys mostly household goods (50\%) and the older age group (55-74) - travel and holiday accommodation, together with those aged 2554 (55 \% both). Mostly e-shoppers spend on their purchase's EUR 100-499 as it is stated in the European Commission data.

Taking into account mentioned numbers authors came to the conclusion that sphere of the Internet nowadays has its unconditional importance. Companies moving online should understand that there are differences between doing business online and offline, and increasing the loyalty level of their customers should be looked in the context of the Internet.

The purpose of the paper is to understand the main differences between consumer loyalty models and e-loyalty models in order to promote business development not only in the traditional environment but also in the online environment. Such research methods as comparative analysis, analysis of the scientific literature, content analysis was used. The 
main focus of the research was on comparing loyalty models in traditional and eenvironment to find out the peculiarities and main features of e-environment.

\section{LOYALTY MODELS}

Scientists such as Dick and Basu (1994) and Oliver (1997) believe that customer loyalty is related to two factors - attitude and behaviour. The similarity of the loyalty factors can be seen in the definition of loyalty of different researchers. Loyalty is the same brand repurchase frequency (Tellis, 1988) as well as the tendency to renew service delivery, according to Andersen and Lanseng (Andreassen, Lanseng, 1997); or subscriptions (Andreassean, Lidestad, 1997) for long-term services.

Consumer loyalty models mainly include components of similar influence, where factors such as trust and satisfaction are most often mentioned. Of course, loyalty patterns are also influenced by the way a company operates. Thus, Nelson Ndubisi (Ndubisi, 2007) adds influential components such as trust, commitment, communication, and conflict resolution to the banking sector's loyalty model. Given the specifics of the banking sector, each of these components does indeed have a significant impact on consumer loyalty.

Conversely, according to the researcher's Lai (Lai, 2009) model of consumer loyalty in the telecommunications sector, quality of service is one of the most important factors in ensuring a positive image of the company and reinforcing the values that the consumer derives, thereby increasing customer satisfaction. The authors of the paper consider that the quality of services is one of the factors that should be emphasized in any service sector.

Nisio and Battista (Nisio, Battista, 2010) associate the consumer loyalty model with the customer satisfaction index, where, of course, the customer satisfaction index is an important factor, which is influenced by the quality received and the customer exponents as well as complaints. The authors want to emphasize that customer expectations are important in both environments.

Employee efficiency is a direct influence on the consumer loyalty model after Akamavi (Akamavi et al., 2015). On the other hand, when considering the proposed Hwang (Hwang, 2019) consumer loyalty model with gaming elements, a factor such as mobile application download intensity appears, which may already be attributed to factors influencing the eloyalty model.

\section{E-LOYALTY MODELS}

Customers of a company's product are specific groups of people. They have their own unique features. They have a specific age, they adhere to a certain lifestyle, differ in their social and material status, etc. And they are focused on special relationships and on a special style of conversation. It is necessary to communicate with them in their language. A company needs to find out what they want and what they need in the first place.

The company's website needs to provide good customer feedback. It should be made clear to them that the company is ready to support them, that it is important for it, that they are interested. There is a need to accumulate information that allows company to better understand customers. The main thing is that the site should be visible willingness and ability of the company to solve the problems of its unique customers. 
Companies should pay attention to their website and ask if it is capable of building customer relationships. In their article, a group of researchers (Yoo et al., 2013) mentions eWOM (word-of-mouth) as an important element that affects e-loyalty. Undoubtedly, modern technologies allow e-WOM to spread quickly and across multiple channels, including social networks. Therefore, when going out online, it is important for the company to rethink communication within these networks as well as their reaction, response and strategy to the negative e-WOM that is spreading uncontrollably.

In the e-environment, on the other hand, the cultural factor plays an important role in eloyalty, as Gracia, Arino and Blasco analyse in their article (Gracia et al., 2015). The authors believe that such a factor is also important because when creating a business on the Internet, one has to understand that there are no borders in the e-environment. On the Internet, shoppers and website visitors are much more likely to be residents of other countries than they would be in a traditional environment. Consequently, companies must be careful in their communication with usage of the correct language and expressions.

Understanding the customer is important and applies to both environments. However, according to statistics, young people are much more likely to visit e-shops and shop there. Therefore, some scholars, such as Purani, Kumar and Sahadey (Purani et al., 2019), highlight exactly the e-loyalty factors that are important to millennials. Factors such as usefulness and ease of use are important in this context. The author points out that this is related to the speed with which the new generation wants to do things online - everything must be quick and simple, and there must be some benefits, both physical and emotional, and so on.

\subsection{Primary e-loyalty influencing factors}

The authors of the paper divided the factors influencing e-loyalty into two groups primary factors and secondary factors. It should be noted that in this case no breakdown was made by age and sex, nor by other characteristics. It was important to divide by the general principle, since most of the world's population makes purchases on the Internet and it is necessary to divide exactly the factors that influence e-loyalty.

Primary factors include the use of communication in the e-environment, the content of the website and the security issues. As already mentioned, it is important to communicate with the client "in his / her language" on the Internet, both in terms of language and communication. Notwithstanding this factor, the company will not only gain a loyal e-buyer, but will be uncompetitive at all. It is also necessary to choose the right communication channel - for the younger generation it would be social networks, for the older one it would be communication via email. Information about the best communication channels could be found at different researches and Marketing Charts.

In order to increase e-loyalty, it is necessary to offer the company customers a convenient, easy-to-use and reliable website with all the necessary information. If it turns out that this information cannot be trusted, for example, the product will be different from the picture, the delivery will be significantly longer than the description, the price on payment will increase, then the company will lose consumer confidence and trust. As a result, the level of e-loyalty will also fall, as losing trust and gaining a negative experience with making an online purchase will result in a dissatisfied customer passing on the negative message and spreading it very quickly throughout the Internet. As it is stated in the MarketLine (2016) Case Study of Amazon Fresh the company "will aim to continue their efforts in service and logistical movements as well as their ability to create a smooth running website that converses to the user just as much as the user connects to the interface". During 
that case study authors found evidence how important website convenience is even for big market players.

Security when shopping, no doubt, helps to increase company's loyalty level. Many consumers nowadays face the negative consequences of using fake e-shops, paying for their purchases on an unsafe site, and so on. According to statistics of European Commission, security when making a purchase is one of the factors that sometimes discourages and stops consumers from making purchases on the Internet at all. Therefore, the company must take care of payment and delivery security and inform about that.

\subsection{Secondary e-loyalty influencing factors}

Secondary e-loyalty factors include additional values, abilities and speed. The authors of the paper emphasize that these factors are not insignificant, but not always as important as the primary ones. When it comes to added value, authors of the paper also need to highlight e-loyalty programs that give customers special points and bonuses that can be used later. As well as, for example, possibility to buy a product or service that is not available in a traditional store. Being able to make purchases using a mobile phone is also an added value, as it saves customer's time, etc. In the report of Millennial Consumers: Understanding key trends driving consumer behaviours authors of the paper found that millennials have a reduced sense of brand loyalty and they need something that would be interesting for them like different promotion programs that help to save some amount of money. Also, AirBnB with its reward system keep their customers coming back according to report of The Future of Travel and Tourism: Technology is driving significant change and growth is on the horizon.

The Internet itself offers many opportunities and capabilities, and some of them increase consumer e-loyalty. The ability to compare all offers within seconds increases e-loyalty to comparison platforms. In turn, the ability to order personalized goods contributes to consumer e-satisfaction. It should be noted that opportunities are important for shoppers who are searching not only for a particular product or service on the Internet, but also for those who are doing it for entertainment, such as listening to music that has just appeared or buying a movie still in the cinemas. According to Blakey (2019) "Almost $60 \%$ of children (8-18 years) say it is more fun than online purchasing with $50 \%$ seeing it as a social event. Ultimately, it is convenience (47\%) and variety (39\%) that means kids online spending is soaring." Authors want to highlight that in case of young e-shoppers such opportunity as having fun during shopping is highly important.

Undoubtedly, a factor such as speed can have a huge impact on e-loyalty. E-shoppers are used to fast things - communication, purchase, delivery, return and / or exchange when needed. Therefore, the speed at which a company responds to a customer's needs must be fast and efficient in order to close all issues of interest and satisfy consumers' expectations as quickly as possible. One should not forget that switching to another alternative in the online environment is very fast and hence the competition is very high. That's why next day delivery is a must for some business spheres such as retail and authors find a proof of that statement in the case study of The Future of Retail: Five ways e-commerce and high street stores are evolving to suit changing consumer behaviours that explains that "super-fast" delivery for the retail should be the main priority for companies and future trends is anonymous delivery which is the next step (MarketLine, 2018). 


\section{CONCLUSION}

The number of customers who purchases online grows rapidly. Depending on their age, sex and other characteristics they make purchases online. When moving online companies should understand their customers and their needs in order to stay competitive. The Internet is a tool, not a strategy. Its unique capabilities are used to improve customer communication, increase organizational acquisition of customer knowledge and increase responsiveness to reduce customer transaction costs and increase convenience. A strategy needs to be developed using that tool.

In case of loyalty in the traditional environment factors such as trust, satisfaction, working efficiency and company's image. Transforming loyalty to e-loyalty influencing factors transforms as well. For e-loyalty company needs to think about Internet influence and such factors as e-WOM, customer culture and communication specifics, website quality, speed and added values. Companies can spend huge amounts of money on attracting traffic, but it should be mentioned that it is much more important to truly understand e-clients, and then take measures to improve the website with this in mind. Providing such a large amount of data, the Internet offers companies unprecedented opportunities in order to get to know customers and tailor offers to their preferences and needs.

\section{REFERENCES}

Akamavi, R.K., Mohamed, E., Pellmann, K., Xu, J. (2015) Key determinants of passenger loyalty in the lowcost airline business. Tourism Management, 46, February 2015, 528-545.

Andreassean, T., \& Lidestad, B. (1997). Customer Loyalty and Complex Services. International Journal of Service Industry Management, 8(4), 1-33. https://doi.org/10.1108/09564239810199923

Andreassen, T. W., \& Lanseng, E. (1997). The principal's and agents' contribution to customer loyalty within an integrated service distribution channel: An external perspective. European Journal of Marketing. https://doi.org/10.1108/03090569710176637

Blakey, D. (2019). Kids online spending soars: children give up on the high street. MarketLine. Retrieved from https:/www.verdict.co.uk/electronic-payments-international/news/kids-online-spending-soars/

Burstein, D. (2015). Marketing Research Chart: Do different age groups prefer different channels? Retrieved from https://www.marketingsherpa.com/article/chart/channels-preferred-by-age-groups

Dick, A. S., \& Basu, K. (1994). Customer Loyalty: Toward an Integrated Conceptual Framework. Journal of the Academy of Marketing Science. https://doi.org/10.1177/0092070394222001

Digital economy and society statistics - households and individuals. (2019). Eurostat. Retrieved: https://ec.europa.eu/eurostat/statistics-explained/index.php/Digital_economy_and_society_statistics__households_and_individuals\#Ordering_or_buying_goods_and_services

E-commerce statistics for individuals. (2019) Eurostat. Retrieved: https://ec.europa.eu/eurostat/statisticsexplained/index.php/E-commerce_statistics_for_individuals\#Most_popular_online_purchases

Gracia, D., Arino, L., Blasco, M. (2015) The effect of culture in forming e-loyalty intentions: A cross-cultural analysis between Argentina and Spain. BRQ Business Research Quarterly (2015) 18, 275-292.

Hwang, J. (2019) Having fun while receiving rewards? Exploration of gamification in loyalty programs for consumer loyalty. Journal of Business Research, https://doi.org/10.1016/i.jbusres. 2019.01.031

Lai, F., Griffin, M., Babin, B. (2009). How quality, value, image, and satisfaction create loyalty at a Chinese telecom. Journal of Business Research, 62, 980-986.

MarketLine. (2016). Amazon Fresh. UK Online Food \& Grocery industry to be disrupted following Amazon entry. MarketLine Case Study. Report Code: ML00022-052. Retrieved from https://store.marketline.com/report/ml00022-052--amazon-fresh-uk-online-food-groceryindustry-to-be-disrupted-following-amazon-entry/

MarketLine. (2017). Millennial Consumers: Understanding key trends driving consumer behaviours. Report Code: ML00026-009. Retrieved from https://store.marketline.com/report/ml00026-009--millennialconsumers-understanding-key-trends-driving-consumer-behaviours/

MarketLine. (2018a). The Future of Retail: Five ways e-commerce and high street stores are evolving to suit changing consumer behaviors. Report Code: ML00026-011. Retrieved from 
https://store.marketline.com/report/ml00026-011--the-future-of-retail-five-ways-e-commerce-and-highstreet-stores-are-evolving-to-suit-changing-consumer-behaviors/

MarketLine. (2018b). The Future of Travel and Tourism: Technology is driving significant change and growth is on the horizon. Report Code: ML00026-015. Retrieved from https://store.marketline.com/report/ml00026-015--the-future-of-travel-tourism-technology-is-drivingsignificant-change-growth-is-on-the-horizon/

Ndubisi, N. O. (2007). Relationship marketing and customer loyalty. Marketing Intelligence \& Planning, 25(1), 98-106.

Nisio, R., Battista, T. (2010). An Application Of The Structural Equation Models To Customer Satisfaction And Loyalty Assessment. Electronic Journal of Applied Statistical Analysis: Decision Support Systems and Services Evaluation EJASA:DSS, 1(1), 42-53. https://doi.org/10.1285/i2037-3627v1n1p42

Oliver, R. L. (1997). Satisfaction: A Behavioral Perspective on the Consumer. Journal of Consumer Marketing, 14. https://doi.org/10.1139/h11-134

Purani, K., Kumar, S., Sahadev, S. (2019). e-Loyalty among millennials: Personal characteristics and social influences. Journal of Retailing and Consumer Services, 48, 215-223. https://doi.org/10.1016/j.jretconser

Tellis, G. J. (1988). Advertising Exposure, Loyalty, and Brand Purchase: A Two-Stage Model of Choice. Journal of Marketing Research, 25, 134-144. https://doi.org/10.2307/3172645

Yoo, C., Sanders, G., Moon, J. (2013). Exploring the effect of e-WOM participation on e-Loyalty in ecommerce. Decision Support Systems, 55, 669-678.

\section{AUTHORS' SHORT BIOGRAPHY}

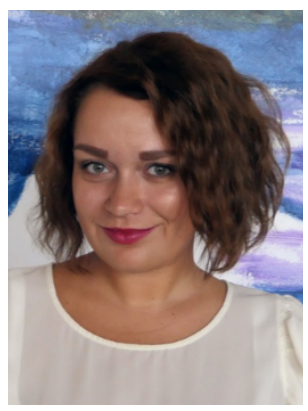

Elina Radionova-Girsa - Received Bachelors and Master's Degree in Management in the University of Latvia, from 2015 is a Ph.D. student. Elina Radionova-Girsa works as a Corporate Training System Specialist in Ecommpay Latvia developing e-learning courses and training programs for the company employees all over the world. Her research interests are Marketing, E-loyalty, Customer Behaviour, Digitalization and Loyalty. All information about publications can be found at her LinkedIn profile.

Author's contact data: e-mail elinaradionova@gmail.com .

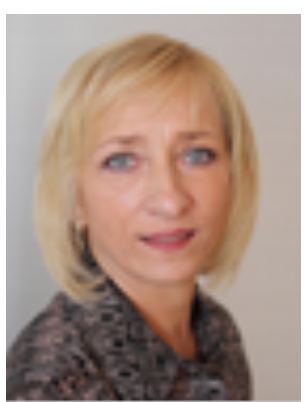

Anda Batraga - Received Bachelors and Master's Degree in Commercial Sciences in the University of Latvia, in 2005 she received the Ph.D. in Economics from the University of Latvia. Anda Batraga is a professor in the University of Latvia, Faculty of Business, Management and Economics; Chairman of the Economic Promotion Council of the University of Latvia; Leading researcher at the University of Latvia, Faculty of Economics and Management and Member of the Council of Management, Member of the Department of Management, Head of Marketing. Her research interests are Marketing. Marketing communications. Branding

Author's contact data: e-mail anda.batraga@lu.lv . 